\title{
Influence of Drying Method on the Composition, Physicochemical Properties, and Prebiotic Potential of Dietary Fibre Concentrates from Fruit Peels
}

\author{
Luis Eduardo Garcia-Amezquita, ${ }^{1}$ Viridiana Tejada-Ortigoza, ${ }^{1}$ Osvaldo H. Campanella, ${ }^{2}$ \\ and Jorge Welti-Chanes $\mathbb{D}^{1}$
}

\author{
${ }^{1}$ Escuela de Ingeniería y Ciencias, Tecnológico de Monterrey, 2501 Eugenio Garza Sada Ave., \\ 64849 Monterrey, NL, Mexico \\ ${ }^{2}$ Food Science Department, Whistler Center for Carbohydrate Research, Purdue University, \\ 745 Agricultural Mall Drive, West Lafayette, IN 47907, USA
}

Correspondence should be addressed to Jorge Welti-Chanes; jwelti@itesm.mx

Received 29 August 2017; Revised 1 June 2018; Accepted 10 June 2018; Published 9 July 2018

Academic Editor: Susana Fiszman

Copyright (C) 2018 Luis Eduardo Garcia-Amezquita et al. This is an open access article distributed under the Creative Commons Attribution License, which permits unrestricted use, distribution, and reproduction in any medium, provided the original work is properly cited.

\begin{abstract}
Dietary fibre concentrates (DFC) obtained from fruit and vegetable by-products are powders, mainly obtained by dehydration, used in food formulations to increase nutritional value and to improve functional properties. The modifications of insoluble, soluble, and total dietary fibres (IDF, SDF, and TDF), physicochemical properties (solubility, swelling capacity, water/oil retention capacity, $\mathrm{pH}$, and tapping density), and prebiotic potential of DFC from orange, mango, and prickly pear peels obtained by freezedrying (FD) and convective hot air-drying (HA) were studied. In vitro faecal fermentation was used to evaluate the short-chain fatty acid (SCFA) production as a prebiotic indicator. TDF in FD orange was $5.5 \mathrm{~g} \cdot 100 \mathrm{~g}^{-1}$ higher than that in the HA sample, whereas HA increased TDF in prickly pear $\left(9.5 \mathrm{~g} \cdot 100 \mathrm{~g}^{-1}\right)$. No differences in fibre composition were observed in mango DFC. The physicochemical properties mostly affected by dehydration treatment were solubility and swelling capacity. HA increased SCFA production in orange peel ( $48 \mathrm{mmol} \cdot \mathrm{g}^{-1}$ higher) but decreased it in mango and prickly pear (15 and $19 \mathrm{mmol} \cdot \mathrm{g}^{-1}$ lower). Butyrate production of HA orange DFC was comparable to that obtained with the positive control $\left(4.5 \mathrm{mmol} \cdot \mathrm{g}^{-1}\right)$. No production of propionate or butyrate was observed after $6 \mathrm{~h}$ fermentation in mango samples, despite the high SDF content $\left(\approx 20 \mathrm{~g} \cdot 100 \mathrm{~g}{ }^{-1}\right)$. A decrease of the SDF: TDF ratio produced by the drying method improved the SCFA production.
\end{abstract}

\section{Introduction}

Dietary fibre has been widely studied due to the health benefits produced by its consumption. A regular ingest of dietary fibre in the diet decreases the cholesterol and glucose levels in the blood $[1,2]$ and reduces the risk of haemorrhoids, colorectal polyps, and diverticulitis as a result of its laxative effect [3]. Dietary fibre could be classified, based on its water solubility, into soluble and insoluble dietary fibres (SDF and IDF, resp.), and SDF is composed of both highand low-molecular weight soluble dietary fibres [4]. The proportion of SDF and IDF, as well as the composition, is related to the physiological and physicochemical properties of the fibres [5].

Fibre used in the food industry is commonly obtained from cereals, but fruit and vegetable sources contain higher proportions of SDF [6], leading to more diverse physicochemical properties. Fibres obtained from fruits and vegetables used by the food industry are frequently obtained using chemical, mechanical, thermal, and enzymatic processes. Most of these treatments involve the use of high amount of solvents, expensive enzymes, long processing time, or the use of high temperature $[7,8]$. For this reason, in the last 20 years, several studies have been focused on the 
characterization $[5,9]$ and application $[10,11]$ of dietary fibre concentrates (DFC) obtained by the dehydration of fruits and vegetables. DFC are composed of less than $9 \%$ lipids and total dietary fibre (TDF) of at least 50\% [12], and they are successfully applied in the food industry [5] to increase nutritional value taking advantage of their physicochemical properties for food formulations. In this regard, some fruit and vegetable by-products, such as peels, pomace, and bagasse, with a high content of dietary fibre, have succeeded in obtaining DFC and their inclusion in foods formulations as functional ingredients [13-15].

Drying is the main unit operation to produce DFC. Water removal increases the powder's shelf life and facilitates its use in food applications. Drying processes modify DFC's physical and chemical properties, whereby the selection of the dehydration method should be accompanied by the characterization of the final properties of DFC [16]. Convective hot air-drying (HA) is the most common dehydration method used to obtain DFC [17]; however, the temperature used in HA has shown to have a negative effect on the DF content and composition which potentially may modify its functional and technological properties [12], whereby freeze-drying (FD) might be used as an alternative. During FD, the water is removed by sublimation under high vacuum and freezing temperatures. The food industry prefers FD over HA because the thermal damage of heatsensible compounds in foods is avoided, preserving some sensory and structural characteristics. However, FD is an expensive process mainly because of the large energy consumption to maintain the sublimation conditions [18]. Besides, the changes produced in the cell wall during the freezing stage could modify the properties of the fibre powders.

Prebiotics are polysaccharides, mainly fermentable dietary fibres, that resist gastric acid, enzymatic hydrolysis, and gastrointestinal absorption. These polysaccharides reach the colonic microbiota conferring benefits to the consumer's health such as the improvement of host immunity, reduction of pathogenic bacterial population, and the production of SCFAs (primarily butyrate, propionate, and acetate) $[19,20]$. Few studies have been reported regarding the prebiotic activity of fruit and/or vegetable by-products. However, these works have been conducted with specific carbohydrates used as prebiotics, chemically or enzymatically extracted. Mandalari et al. [21] studied the in vitro prebiotic activity of pectic oligosaccharides from bergamot peel. They demonstrated a higher prebiotic potential of the bergamot peel oligosaccharides than that of the fructooligosaccharides (FOS) used as a control. A similar study was performed by Rubel et al. [22] using inulin-type carbohydrates from Jerusalem artichoke as prebiotics, which showed better prebiotic activity than commercial inulin. For their part, Reis et al. [23] found larger SCFA production and lactate concentrations after a faecal fermentation of arabinoxylans extracted from brewer's spent grain than that in cultures containing FOS. In vitro faecal fermentation of agave fructans was conducted by Gomez et al. [24], evaluating changes in the bacterial population and SCFA production. Nevertheless, to our knowledge, only prickly pear and pineapple peels [25] and tiger nut coproducts [26] have been used to study the prebiotic potential of DFC. The prebiotic potential in these studies was demonstrated by plate microbial growth curves and quantification of SCFAs from culture media, but faecal fermentation of DFC has not been verified. The objective of this research was to evaluate changes in the dietary fibre composition and physicochemical properties of DFC from orange, mango, and prickly pear peels, produced by FD and HA methods. Also, the influence of these drying methods on the DFC's prebiotic potential was evaluated through SCFA production after in vitro faecal fermentation.

\section{Materials and Methods}

2.1. Materials. Orange (Citrus sinensis cv. Valencia) bagasse (peel, seeds, and pulp) was provided by a local juice producer (Central Market, Guadalupe, NL, Mexico) immediately after the juice extraction process. Prickly pear (Opuntia ficusindica $\mathrm{cv}$. Verde Villanueva) was provided by the producer "La Flor de Villanueva" (Acatzingo, Puebla, Mexico). Mango (Mangifera indica cv. Ataulfo) peel was provided by a local food-processing company "Genius Foods" (Monterrey, NL, Mexico). Samples of orange juice and mango pulp obtained from the same batch of the by-products were also provided to evaluate the fruit maturity stage. Orange and mango peels were kept at $4^{\circ} \mathrm{C}$ for no more than $4 \mathrm{~h}$ before sample preparation. Enzymatic kit for DF analysis (K-INTDF 06/13) and ion exchange resins (Amberlite FPA53 ${ }^{\circledR}\left(\mathrm{OH}^{-}\right)$and Ambersep $200^{\circledR}\left(\mathrm{H}^{+}\right)$) were obtained from Megazyme (Wicklow, LEN, Ireland). All reagents for DF, protein, and fat quantification, chromatographic standards, $\mathrm{P}_{4} \mathrm{O}_{10}$, and SCFA determination were obtained from Sigma-Aldrich (St. Louis, MO, USA).

2.2. Sample Preparation. Orange peel (albedo and flavedo) was manually obtained by removing pulp and seed residues. Prickly pear fruits and mango and orange peels were sanitized in a sodium hypochlorite solution for $10 \mathrm{~min}$. Prickly pears were manually peeled, and pulp and seeds were discarded. For maturity stage identification, $500 \mathrm{~mL}$ of prickly pear pulp was stored. In the case of DFC from freeze-dried orange, mango, and prickly pear peels, fresh fruit peels were grounded (VM0103; Vitamix, Cleveland, OH, USA) and frozen at $-50^{\circ} \mathrm{C}$ for $24 \mathrm{~h}$. Frozen samples were freeze-dried at $-50^{\circ} \mathrm{C}$ and 2.0 mbar (Labconco, Kansas City, MO, USA), hand-milled, and sieved through 40 mesh. In the case of DFC from orange, mango, and prickly pear peels obtained by convective hot air-drying (HA), fruit peels were dried using a convective hot air dehydrator (model IME-08; EDEL Ingenieros, Monterrey, NL, Mexico) at $55 \pm 5^{\circ} \mathrm{C}$ and air flow rate of $1.5 \mathrm{~m} \cdot \mathrm{s}^{-1}$ for $12 \mathrm{~h}$ until constant weight was obtained. Dried samples were grounded in a pilot plant scale hammer mill (model 200; Pulvex, Mexico City, Mexico) and sieved through 40 mesh $(425 \mu \mathrm{m})$. Powders were stored in desiccators containing $\mathrm{P}_{4} \mathrm{O}_{10}$ at $25^{\circ} \mathrm{C}$ to avoid sample humidification before analysis. 
2.3. Proximate Composition. Moisture, protein $(\mathrm{N} \times 6.25)$, ash, and fat content from dried samples were determined following the AOAC Official Methods 920.151, 920.152, 940.26 , and 960.39 , respectively. All proximate results, except for the moisture content, were reported on dry basis (db). The titratable acidity and soluble solids from fresh juice (orange) and pulp (mango and prickly pear) were evaluated according to the AOAC Methods 942.15 and 932.12 [27], respectively. Titratable acidity was expressed as g of citric acid per kg of juice. The maturity index was calculated as the soluble solids ( ${ }^{\circ}$ Brix) : titratable acidity $\left(\mathrm{g} \cdot \mathrm{kg}^{-1}(\mathrm{wb})\right)$ ratio.

2.4. Dietary Fibre Evaluation. IDF and high- and lowmolecular weight soluble dietary fibres (referred as SDFP and SDFS, resp., depending on the precipitation or solubilization in the presence of $76 \%$ ethanol) were evaluated following the AOAC 2011.25 procedure proposed by McCleary [28] with some modifications previously reported by Tejada-Ortigoza et al. [8], using the Megazyme integrated total dietary fibre kit (Megazyme International Ireland, Wicklow, Ireland). SDF was obtained as the sum of SDFP and SDFS, whereas total dietary fibre (TDF) was obtained as the sum of SDF and IDF. To quantify the SDFS fraction, a Waters 717 plus autosampler operating at $4^{\circ} \mathrm{C}$ was used to inject samples from vials to the liquid chromatograph. SDFS was separated through a Bio-Rad Aminex ${ }^{\circledR}$ column $(300 \times 7.8 \mathrm{~mm})$ at $90^{\circ} \mathrm{C}$, with a flow rate of $0.5 \mathrm{~mL} \cdot \mathrm{min}^{-1}$ of $\mathrm{Na}_{2} \mathrm{Ca}$-EDTA $\left(50 \mathrm{mg} \cdot \mathrm{L}^{-1}\right)$, and analyzed with a Waters refractive index detector 2414 set at $50^{\circ} \mathrm{C}$.

\subsection{Physicochemical Properties}

2.5.1. Solubility (SOL). The DFC solubility was obtained with samples $(200 \mathrm{mg})$ suspended in water $(30 \mathrm{~mL})$ in $50 \mathrm{~mL}$ parafilm-covered beakers and stirred for $3 \mathrm{~h}$ at $25^{\circ} \mathrm{C}$. Suspensions were placed in $50 \mathrm{~mL}$ centrifuge tubes and centrifuged $\left(3000 \times g, 22^{\circ} \mathrm{C}\right.$, and $\left.20 \mathrm{~min}\right)$. The supernatant was carefully discarded, and the pellet was washed with $10 \mathrm{~mL}$ of distilled water and filtered using a filter paper (Whatman no. 41). The filter paper with the pellet was airdried at $60^{\circ} \mathrm{C}$ for $24 \mathrm{~h}$. SOL was calculated using the following equation:

$$
\mathrm{SOL}=\frac{W_{\mathrm{S}}-W_{\mathrm{DP}}}{W_{\mathrm{S}}} \times 100,
$$

where SOL is the solubility of the sample expressed as a percentage and $W_{\mathrm{S}}$ and $W_{\mathrm{DP}}$ are the weight of the sample $(\mathrm{db})$ and the weight of the dried pellet, discarding the filter paper weight, respectively, expressed in g.

2.5.2. Swelling Capacity (SC). Defined as the resulting volume of the sample after hydration, SC was obtained suspending $200 \mathrm{mg}$ of the DFC with distilled water $(10 \mathrm{~mL})$ in a foil-covered graduated test tube. Suspensions were manually stirred with a glass tube to avoid agglomerations. After $24 \mathrm{~h}$ at $25^{\circ} \mathrm{C}$, the volume of the precipitate was achieved. SC was calculated using the following equation:

$$
\mathrm{SC}=\frac{V_{\mathrm{P}}}{W_{\mathrm{S}}},
$$

where SC is the swelling capacity of the sample expressed as $\mathrm{mL} \cdot \mathrm{g}^{-1}$ and $V_{\mathrm{P}}$ is the volume of the precipitate obtained after hydration expressed in $\mathrm{mL}$.

2.5.3. Water Retention Capacity (WRC). This parameter was attained using the methodology proposed by Chau and Huang [29] with some modifications. DFC (1 g) were placed in $50 \mathrm{~mL}$ foil-covered beakers with $10 \mathrm{~mL}$ of distilled water and continuously stirred for $18 \mathrm{~h}$ at $25^{\circ} \mathrm{C}$. Suspensions were carefully placed in $15 \mathrm{~mL}$ graduated tubes and centrifuged $\left(4,500 \times g, 22^{\circ} \mathrm{C}\right.$, and $\left.30 \mathrm{~min}\right)$. The volume of the supernatant and the precipitate was recorded. The WRC was calculated using the following equation:

$$
\mathrm{WRC}=\frac{10-V_{\mathrm{S}}}{W_{\mathrm{S}}},
$$

where WRC is the water retention capacity of the sample expressed as $\mathrm{mL} \cdot \mathrm{g}^{-1}$ and $V_{\mathrm{S}}$ is the volume of the supernatant obtained by centrifugation expressed in $\mathrm{mL}$.

2.5.4. Oil Retention Capacity (ORC). Oil retention capacity was obtained similarly to WRC but using soybean oil instead of distilled water. ORC is expressed as $\mathrm{mL} \cdot \mathrm{g}^{-1}$.

2.5.5. $\mathrm{pH}$. Five grams of DFC were suspended in $50 \mathrm{~mL}$ of distilled water and stirred for 5 minutes. $\mathrm{pH}$ was measured immediately using a $\mathrm{pH}$ meter (Orion 3-Star, Thermo Scientific, USA) at $25^{\circ} \mathrm{C}$.

2.5.6. Tapping Density (TD). Tapping density was determined by placing the DFC in graduated test tubes until they reached $10 \mathrm{~mL}$ and recording the weight $(\mathrm{db})$. The test tube was tapped on a table for 5 minutes. The final volume after tapping was recorded $\left(V_{\mathrm{T}}\right)$. TD $\left(\mathrm{mg} \cdot \mathrm{mL}^{-1}\right)$ was calculated as follows:

$$
\mathrm{TD}=\frac{V_{\mathrm{T}}}{W_{\mathrm{S}}}
$$

2.6. In Vitro Fermentation of DFC. All the experiments of the in vitro fermentation of DFC were performed in the facilities of the Whistler Center for Carbohydrate Research at Purdue University, West Lafayette, IN, USA.

2.6.1. Sample Preparation. The samples for in vitro fermentation were prepared following the methodology adapted by Rose et al. [30]. FD and HA samples $(6 \mathrm{~g})$ were suspended in $84 \mathrm{~mL}$ of $20 \mathrm{mM}$ phosphate buffer ( $\mathrm{pH} 6.9$, $10 \mathrm{mM} \mathrm{NaCl}$ ) and heated for $20 \mathrm{~min}$ in a boiling water bath. Samples were cooled down and placed in a shaking water bath at $37^{\circ} \mathrm{C}$ for enzymatic digestions. The first digestion was conducted with salivary $\alpha$-amylase for $15 \mathrm{~min}$, followed by a $30 \mathrm{~min}$ digestion with porcine pepsin and a $90 \mathrm{~min}$ digestion with porcine pancreatin. All enzymatic digestions 
were performed at $150 \mathrm{rpm}$. Digested samples were dialyzed against distilled water for $26 \mathrm{~h}$ (Spectra/Por1; MW cutoff 6-8000 Da; Spectrum Labs, Rancho Dominguez, USA)

2.6.2. Faecal Slurry Preparation. Fresh human faecal samples were obtained from three healthy adult donors, one woman and two men between 25 and 30 years. Volunteers consumed their normal diet, had no history of gastrointestinal abnormalities in the last 6 months, and had not taken antibiotics for at least 3 months. The samples were collected on the morning of the experiment into sterile vials using a commode specimen collection system. Faeces were kept at $4^{\circ} \mathrm{C}$ before use, for no more than $2 \mathrm{~h}$ after collection. To obtain the faecal slurry, equal weights obtained from the internal part of the faecal samples were pooled and combined with carbonate : phosphate buffer $(1: 10)$, following by a filtration through 4 layers of cheese cloth. Donors signed an informed consent before the experiment initiation, and all experimental protocols were approved by the Institutional Review Board at Purdue University (IRB protocol \#1510016635).

2.6.3. Inoculation and In Vitro Fermentation. In vitro fermentation of DFC was conducted in an anaerobic chamber $\left(85 \% \mathrm{~N}_{2}, 5 \% \mathrm{CO}_{2}\right.$, and $\left.10 \% \mathrm{H}_{2}\right)$ following the methodology adapted by Tuncil et al. [31]. Cysteine $(0.1 \mathrm{~g} / \mathrm{mL})$ was added into sterilized carbonate-phosphate buffer $\left(0.25 \mathrm{~g} \cdot \mathrm{L}^{-1}\right)$, and oxygen was removed bubbling with carbon dioxide. The buffer was conditioned in the anaerobic chamber overnight. $44 \pm 0.5 \mathrm{mg}$ of dialyzed dietary fibre concentrate samples was placed in test tubes (4 tubes per sample were considered for each fermentation point, i.e., $0,6,12$, and $24 \mathrm{~h}$ ) and located into the anaerobic chamber (FOS were used as a positive control), where $4 \mathrm{~mL}$ of the conditioned carbonate-phosphate buffer was added to each tube. Then, each tube was inoculated with $0.4 \mathrm{~mL}$ of the faecal slurry, sealed with rubber stoppers, and incubated in a water bath at $37^{\circ} \mathrm{C}$ and $150 \mathrm{rpm}$. Blank test tubes per each time point were prepared with no substrate addition.

2.7. Short-Chain Fatty Acid (SCFA) Quantification. SCFA quantification was conducted following the methodology described by Rose et al. [30]. Briefly, for each fermentation time point, $0.4 \mathrm{~mL}$ of the fermented samples was collected and mixed with $100 \mu \mathrm{L}$ of a mixture of 4-methylvaleric acid, 85\% phosphoric acid, and copper sulphate pentahydrate $(157.5 \mu \mathrm{L}, 1.47 \mathrm{~mL}$, and $9 \mathrm{~g}$, resp.), used as an internal standard. $400 \mu \mathrm{L}$ of copper sulphate $\left(2.75 \mathrm{mg} \cdot \mathrm{mL}^{-1}\right)$ was added to stop fermentation, and purified water was used to obtain a final volume of $25 \mathrm{~mL}$. The samples were kept at $-80^{\circ} \mathrm{C}$ until further analysis. Defrosted samples were centrifuged for $10 \mathrm{~min}$ at $3000 \times g$ (Microfuge 20R; Beckman Coulter, Brea, CA), and $4 \mu \mathrm{L}$ of the supernatant was injected into the gas chromatograph (5890 Series II, Hewlett Packard, Palo Alto, CA) equipped with a fused silica capillary column (Nukol; Supelco nr 40369-03A, Bellefonte, PA) to separate fatty acids. SCFAs were identified with a flame ionization
TABLE 1: Maturity stage parameters of orange, mango, and prickly pear.

\begin{tabular}{lccc}
\hline & Orange & Mango & Prickly pear \\
\hline Soluble solids $\left({ }^{\circ} \mathrm{Bx}\right)$ & $15.0 \pm 0.0$ & $23.4 \pm 0.5$ & $16.8 \pm 0.0$ \\
Titratable acidity $\left(\mathrm{g} \cdot \mathrm{kg}^{-1}\right)^{*}$ & $6.9 \pm 0.3$ & $10.7 \pm 1.4$ & $1.8 \pm 0.3$ \\
Maturity index $^{* *}$ & $2.2 \pm 0.1$ & $2.2 \pm 0.3$ & $9.3 \pm 1.3$ \\
\hline
\end{tabular}

Values are mean of three determinations $\pm \mathrm{SD}$; ${ }^{*} \mathrm{~g}$ of citric acid per $\mathrm{kg}$ of fruit pulp (wb); ${ }^{* *}$ soluble solids/titratable acidity.

detector (GC-FID 7890A; Agilent Technologies, Santa Clara, CA). A standard mix (Supelco, Bellefonte, PA) was injected to determine acetate, propionate, and butyrate relative to 4-methylvaleric acid. Concentration of SCFAs is expressed as mmol per $1 \mathrm{~g}(\mathrm{db})$ of DFC.

2.8. Statistical Analysis. All experiments were performed in quadruplicate, except for SCFA quantification which was conducted in triplicate. Experimental data were analyzed using the Minitab statistical software V. 14.1 (Minitab Ltd., Coventry, UK). Comparison of means was evaluated by oneway ANOVA, followed by Tukey's multiple comparison test to find significant differences between treatments $(p<0.05)$.

\section{Results and Discussion}

3.1. Proximate Composition of Dehydrated Fruit Peels. The soluble solids and titratable acidity and their ratio (maturity index) of the orange, mango, and prickly pear are shown in Table 1. These parameters were used to characterize the ripening stage of the fruits which is related to the content of digestible and nondigestible carbohydrates (i.e., dietary fibre). Maturity index confirmed that all the fruits were at an edible ripening stage [32-34].

The composition of the DFC studied is given in Table 2; the final moisture content obtained after the dehydration process ranged from 1.3 to $3.5 \mathrm{~g} \cdot 100 \mathrm{~g}^{-1}$ wb. A similar final moisture content of diverse DFC from fruit by-products has been reported previously. Peerajit et al. [35] obtained a final moisture of $0.05 \mathrm{~kg} \cdot \mathrm{kg}^{-1} \mathrm{db}$ (i.e., $4.8 \mathrm{~g} \cdot 100 \mathrm{~g}^{-1} \mathrm{wb}$ ) in lime residue dietary fibre powder dried at $60^{\circ} \mathrm{C}$ in a hot air oven. Watermelon rind concentrates obtained by Naknaen et al. [36] using a hot air oven at $60^{\circ} \mathrm{C}$ showed a final moisture of $5.4 \mathrm{~g} \cdot 100 \mathrm{~g} \mathrm{~g}^{-1} \mathrm{wb}$. Freeze-dried date fibres obtained by Ahmed [37] showed final moistures from 2.8 to $4.9 \mathrm{~g} \cdot 100 \mathrm{~g}^{-1} \mathrm{wb}$. The final moisture contents depicted in Table 2 show no significant differences $(p<0.05)$ between drying technologies utilized for mango peel DFC; however, orange and prickly pear samples dried by HA exhibited a significantly higher moisture content $(p<0.05)$ than FD samples $(2.1$ and $1.3 \mathrm{~g} \cdot 100 \mathrm{~g}^{-1} \mathrm{wb}$ for HA and FD orange, and 3.5 and $2.8 \mathrm{~g} \cdot 100 \mathrm{~g}^{-1} \mathrm{wb}$ for HA and FD prickly pear, resp.). Similar differences in the final moisture content between methodologies were reported by Hsu et al. [38] in yam flours, who obtained a moisture of $0.6 \mathrm{~g} \cdot 100 \mathrm{~g}^{-1}$ wb in FD samples compared to $5.4 \mathrm{~g} \cdot 100 \mathrm{~g}^{-1} \mathrm{wb}$ in flours attained by HA. These differences could be explained by two different effects: (1) the long drying duration at high temperatures in HA seals the surface capillaries of the samples reducing the water 
TABle 2: Proximate composition ( $\mathrm{g} \cdot 100 \mathrm{~g}^{-1} \mathrm{db}$ ) of dietary fibre concentrates from orange, mango, and prickly pear peels freeze-dried (FD) and convective hot air-dried (HA).

\begin{tabular}{|c|c|c|c|c|c|c|}
\hline & \multicolumn{2}{|c|}{ Orange } & \multicolumn{2}{|c|}{ Mango } & \multicolumn{2}{|c|}{ Prickly pear } \\
\hline & FD & $\mathrm{HA}$ & FD & $\mathrm{HA}$ & FD & $\mathrm{HA}$ \\
\hline Final moisture (wb) & $1.3 \pm 0.2^{\mathrm{b}}$ & $2.1 \pm 0.1^{\mathrm{a}}$ & $2.5 \pm 0.3^{\mathrm{a}}$ & $1.9 \pm 0.4^{\mathrm{a}}$ & $2.8 \pm 0.3^{\mathrm{a}}$ & $3.5 \pm 0.3^{b}$ \\
\hline Protein $(\mathrm{N} \times 6.25)$ & $3.6 \pm 0.2^{b}$ & $4.9 \pm 0.1^{\mathrm{a}}$ & $4.1 \pm 0.1^{\mathrm{a}}$ & $3.8 \pm 0.1^{\mathrm{a}}$ & $6.1 \pm 0.2^{\mathrm{a}}$ & $4.4 \pm 0.3^{\mathrm{b}}$ \\
\hline Fat & $1.1 \pm 0.5^{\mathrm{a}}$ & $1.5 \pm 0.1^{\mathrm{a}}$ & $2.1 \pm 0.4^{\mathrm{a}}$ & $1.4 \pm 0.8^{\mathrm{a}}$ & $1.6 \pm 0.2^{\mathrm{a}}$ & $1.3 \pm 0.3^{\mathrm{a}}$ \\
\hline Ash & $3.1 \pm 0.2^{\mathrm{b}}$ & $4.2 \pm 0.1^{\mathrm{a}}$ & $3.9 \pm 0.2^{\mathrm{a}}$ & $2.9 \pm 0.2^{\mathrm{b}}$ & $21.6 \pm 0.2^{\mathrm{a}}$ & $18.8 \pm 1.0^{\mathrm{a}}$ \\
\hline Carbohydrates* & $92.2 \pm 0.4$ & $89.4 \pm 0.1$ & $89.9 \pm 0.3$ & $91.9 \pm 0.5$ & $70.7 \pm 0.2$ & $75.6 \pm 0.6$ \\
\hline
\end{tabular}

Values are mean of three determinations \pm SD. Values per fruit (freeze-dried or convective hot air-dried) within the same row followed by different letters are significantly different $(p<0.05) .{ }^{*}$ Carbohydrate content includes digestible and nondigestible carbohydrates (i.e., dietary fibre) and was calculated by difference.

TABLE 3: Dietary fibre composition ( $\mathrm{g} \cdot 100 \mathrm{~g}^{-1} \mathrm{db}$ ) of dietary fibre concentrates from orange, mango, and prickly pear peels freeze-dried (FD) and convective hot air-dried (HA).

\begin{tabular}{|c|c|c|c|c|c|c|}
\hline & IDF & SDFP & SDFS & SDF & TDF & SDF :TDF \\
\hline \multicolumn{7}{|c|}{ Orange } \\
\hline FD & $46.3 \pm 1.2^{\mathrm{a}}$ & $5.6 \pm 0.3^{\mathrm{a}}$ & $1.7 \pm 0.2^{\mathrm{a}}$ & $7.4 \pm 0.4^{\mathrm{a}}$ & $54.7 \pm 0.9^{\mathrm{a}}$ & 0.14 \\
\hline HA & $42.7 \pm 0.5^{\mathrm{b}}$ & $5.6 \pm 0.2^{\mathrm{a}}$ & $0.9 \pm 0.0^{\mathrm{b}}$ & $6.4 \pm 0.3^{\mathrm{b}}$ & $49.2 \pm 0.0^{\mathrm{b}}$ & 0.13 \\
\hline \multicolumn{7}{|c|}{ Mango } \\
\hline $\mathrm{FD}$ & $33.4 \pm 0.8^{\mathrm{a}}$ & $19.5 \pm 0.2^{\mathrm{a}}$ & $2.2 \pm 0.5^{\mathrm{a}}$ & $21.8 \pm 0.8^{\mathrm{a}}$ & $54.8 \pm 1.3^{\mathrm{a}}$ & 0.40 \\
\hline $\mathrm{HA}$ & $32.3 \pm 1.3^{\mathrm{a}}$ & $20.1 \pm 0.6^{\mathrm{a}}$ & $0.8 \pm 0.0^{\mathrm{b}}$ & $20.8 \pm 0.4^{\mathrm{a}}$ & $53.0 \pm 1.3^{\mathrm{a}}$ & 0.39 \\
\hline \multicolumn{7}{|c|}{ Prickly pear } \\
\hline $\mathrm{FD}$ & $34.0 \pm 0.6^{\mathrm{b}}$ & $4.7 \pm 0.2^{\mathrm{b}}$ & $1.4 \pm 0.2^{\mathrm{a}}$ & $6.1 \pm 0.3^{\mathrm{b}}$ & $40.0 \pm 0.9^{\mathrm{b}}$ & 0.15 \\
\hline $\mathrm{HA}$ & $40.7 \pm 6.0^{\mathrm{a}}$ & $12.3 \pm 7.5^{\mathrm{a}}$ & $1.4 \pm 1.0^{\mathrm{a}}$ & $13.3 \pm 7.8^{\mathrm{a}}$ & $49.2 \pm 5.6^{\mathrm{a}}$ & 0.27 \\
\hline
\end{tabular}

Values are mean of four determinations \pm SD. Values per fruit (freeze-dried or convective hot air-dried) within the same column followed by different letters are significantly different $(p<0.05)$. IDF: insoluble dietary fibre; SDFP: high-molecular weight soluble dietary fibre; SDFS: low-molecular weight soluble dietary fibre; SDF: soluble dietary fibre; TDF: total dietary fibre.

releasing from the matrix [39], and (2) the increase of carbohydrate content, mainly digestible carbohydrates, that is, carbohydrates without including dietary fibre, (data not shown) may reduce the moisture content and monolayer water content of the matrixes due to the cross-linking of the carbohydrates with other compounds of the samples limiting the sites to absorb moisture [40].

Low contents of fat and protein were observed in all samples, the maximum fat value was found in FD mango peel DFC (2.1 g. $\left.100 \mathrm{~g}^{-1} \mathrm{db}\right)$, and FD prickly pear peel DFC showed the highest protein content $\left(6.1 \mathrm{~g} \cdot 100 \mathrm{~g}^{-1} \mathrm{db}\right)$. The ash content of prickly pear, independently of the drying method, was notably higher than that of mango and orange samples. Similar ash content was reported by TejadaOrtigoza et al. [8] for FD concentrates from prickly pear peels and by Nharingo and Moyo [41] in Opuntia ficus cladodes, which have a similar composition as that of the prickly pear peel. On the contrary, FD orange and HA mango DFC exhibited the highest carbohydrate content (92.2 and $91.9 \mathrm{~g} \cdot 100 \mathrm{~g}^{-1} \mathrm{db}$, resp.), while the FD prickly pear peel sample showed $70.7 \mathrm{~g} \cdot 100 \mathrm{~g}^{-1} \mathrm{db}$.

Regarding TDF content (Table 3), all concentrates showed values ranging from 40.0 to $54.8 \mathrm{~g} \cdot 100 \mathrm{~g}^{-1} \mathrm{db}$ (FD prickly pear and FD mango peel DFC, resp.), indicating that the concentrates studied might be considered as a source of dietary fibre. Similar TDF contents have been reported in several DFC from fruit by-products (obtained similarly to those studied in this research): for example, pineapple peel $\left(45.2 \mathrm{~g} \cdot 100 \mathrm{~g}^{-1} \mathrm{db}\right)[42]$, pomegranate pomace $\left(56.3 \mathrm{~g} \cdot 100 \mathrm{~g}^{-1} \mathrm{db}\right)$ [43], orange peel $\left(49.2 \mathrm{~g} \cdot 100 \mathrm{~g}^{-1} \mathrm{db}\right)[44]$, grapefruit peel $\left(44.2 \mathrm{~g} \cdot 100 \mathrm{~g}^{-1} \mathrm{db}\right)[5]$, melon peel (50.2 g. $100 \mathrm{~g}^{-1} \mathrm{db}$ ) [45], mango peel (51.2 g. $100 \mathrm{~g}^{-1}$ db) [46], prickly pear peel $\left(38.1 \mathrm{~g} \cdot 100 \mathrm{~g}^{-1} \mathrm{db}\right)$ [44], and red grape peel $\left(53.2 \mathrm{~g} \cdot 100 \mathrm{~g}^{-1} \mathrm{db}\right)$ [47], among others. Analyzing the effect of dehydration processes, the TDF, IDF, and SDF (as the sum of SDFP and SDFS) contents in FD and HA mango samples showed no significant differences $(p<0.05)$. Even a slight decrease in SDFS content was observed for the HA concentrate $\left(0.8 \mathrm{~g} \cdot 100 \mathrm{~g}^{-1} \mathrm{db}\right)$, compared to that of the FD concentrate $\left(2.2 \mathrm{~g} \cdot 100 \mathrm{~g}^{-1} \mathrm{db}\right)$; no significant effect on the SDF value was observed.

A lower TDF content in orange peel DFC was observed in HA samples $\left(49.2 \mathrm{~g} \cdot 100 \mathrm{~g}^{-1} \mathrm{db}\right)$ when compared to FD samples $\left(54.7 \mathrm{~g} \cdot 100 \mathrm{~g}^{-1} \mathrm{db}\right)$. The TDF reduction resulted from a decrease in the IDF and SDF values, both because of the use of the thermal process in the HA process. The same observation was reported by Vega-Gálvez et al. [48] in Cape gooseberry, where the TDF content decreases from $53.5 \mathrm{~g} \cdot 100 \mathrm{~g}^{-1} \mathrm{db}$ in fresh fruit to $37.0 \mathrm{~g} \cdot 100 \mathrm{~g}^{-1} \mathrm{db}$ after convection drying at $60^{\circ} \mathrm{C}$, resulted by a decrease in the content of both IDF and SDF. As depicted in Table 3, the IDF content of HA orange peel DFC was lower than that of the FD sample. The main components of orange peel IDF are insoluble pectins $[44,49]$, which could be modified by deesterification, via pectin-methyl-esterase enzyme's activity promoted at mild temperatures [50], and potentially turned into digestible carbohydrates. Regarding SDF fraction, HA orange peel showed lower content compared to that of the FD sample, mainly by the reduction of the low-molecular weight fraction, since SDFP fraction remained similar among treatments. This reduction in the SDFS content in 
orange peel is due to the effect of the temperature used in HA, since SDFS is composed of FOS, particularly 1-kestose and $1^{\mathrm{F}}$ - $\beta$-fructofuranosylnystose $[44,51]$, and both compounds are highly hydrolyzable with the use of temperature [52]. On the contrary, a significantly higher TDF content was observed in HA prickly pear DFC $\left(49.2 \mathrm{~g} \cdot 100 \mathrm{~g}^{-1} \mathrm{db}\right)$ when compared to FD samples $\left(40.0 \mathrm{~g} \cdot 100 \mathrm{~g}^{-1} \mathrm{db}\right)$, due to an increment in both IDF and SDFS. The decrease in the fibre content of orange DFC and the increase in that of the prickly pear samples produced by the HA treatment were also observed by Tejada-Ortigoza et al. [8] even with different treatments, such as high hydrostatic pressure. However, more research is needed to understand the effect of temperature on the increase of the DF fractions and carbohydrate modification of prickly pear peel.

3.2. Physicochemical Properties of DFC. The results obtained for physicochemical properties are shown in Table 4. SOL of FD and HA concentrates ranged from 34.4 to $53.9 \%$ (FD orange peel and FD prickly pear peel concentrates, resp.). SOL in FD mango and prickly pear samples was higher than the one obtained by HA. On the contrary, HA orange peel was more soluble than the FD concentrate. Similar to these, last results were obtained by Que et al. [53], where HA pumpkin powder showed a higher solubility than the FD sample (34.9 and 30.7\%, resp.). A negative correlation $\left(R^{2}=0.67\right)$ between SOL and IDF content of the dehydrated samples was observed (Figure 1(a)). IDF is the fibre fraction that is not soluble in water; therefore, samples with higher original IDF content or increased by the dehydration process exhibited lower SOL. This behaviour is comparable to that reported by Huang and $\mathrm{Ma}$ [54], where a reduction in the IDF content of orange pomace from 46.5 to $33.6 \%$ (db) increased SOL from 2.8 to $30.6 \%$.

On the contrary, SC values ranging from 6.5 to $11.2 \mathrm{~mL} \cdot \mathrm{g}^{-1}(\mathrm{db})$ were achieved (HA mango and FD prickly pear concentrates, resp.). Similar SC values (from 4.6 to $7.2 \mathrm{~mL} \cdot \mathrm{g}^{-1}$ ) were also observed by Martínez et al. [55] in mango, passion fruit, and pineapple DFC and by Figuerola et al. [5] in apple and orange peel concentrates (from 6.1 to $\left.9.2 \mathrm{~mL} \cdot \mathrm{g}^{-1}\right)$. Higher SC values were obtained in FD prickly pear and mango peel DFC than in HA samples. Nevertheless, in the case of orange peel HA samples, the SC values were significantly higher $(p<0.05)$ than FD concentrates $\left(10.6\right.$ and $8.1 \mathrm{~mL} \cdot \mathrm{g}^{-1}$, resp.). The TDF content of the studied samples seems to have an influence on the decrease of the $\mathrm{SC}$, as it is shown in Figure $1(\mathrm{~b})\left(R^{2}=0.61\right)$. Comparable behaviour was observed in the results published by O'Shea et al. [56] in orange and apple pomace concentrates, where orange pomace with a TDF content of 40.5 showed an SC of $8.1 \mathrm{~mL} \cdot \mathrm{g}^{-1}$, whereas apple pomace concentrates with a TDF content of $30.2 \mathrm{~g} \cdot 100 \mathrm{~g}^{-1}$ exhibited an SC of $12.8 \mathrm{~mL} \cdot \mathrm{g}^{-1}$.

The studied DFC showed a low capacity to bind water (from 3.2 to $4.4 \mathrm{~mL} \cdot \mathrm{g}^{-1}$ ), as it is shown in Table 4, compared to other studies. López-Marcos et al. [43] obtained DFC from lemon, grapefruit, pomegranate, and tiger nut bagasse with WRC up to $8.0 \mathrm{~mL} \cdot \mathrm{g}^{-1}$. The low WRC values reached in the present research could be due to the DFC particle size (up to $425 \mu \mathrm{m}$ ). Chantaro et al. [57] reported that carrot peel DFC with a particle size of $150-250 \mu \mathrm{m}$ exhibited higher WRC than the one with a particle size of $300-450 \mu \mathrm{m}$. Raghavendra et al. [58] proved that both WRC and ORC values in coconut residue DFC were higher at the determined particle size and reduced their value at higher and lower particle sizes. They proved that the particle size to obtain the maximum WRC/ORC value depends on the microstructure. When comparing WRC between drying methods, minor but significant differences $(p<0.05)$ were observed. HA samples resulted in lower values than the FD samples in the evaluated fruit peels. A correlation between WRC and SDFS is shown in Figure $1(\mathrm{c})\left(R^{2}=0.70\right)$. On the contrary, ORC values ranged from 1.7 to $2.6 \mathrm{~mL} \cdot \mathrm{g}^{-1}$. No significant differences $(p<0.05)$, related with the effect of the drying method applied, were found in mango DFC. ORC in HA orange peel concentrates was higher than the one obtained by FD ( 2.5 and $1.8 \mathrm{~mL} \cdot \mathrm{g}^{-1}$, resp.), contrary to prickly pear DFC samples where the HA sample value $\left(1.8 \mathrm{~mL} \cdot \mathrm{g}^{-1}\right)$ was lower when compared to the FD sample $\left(2.6 \mathrm{~mL} \cdot \mathrm{g}^{-1}\right)$. This result agrees with Que et al. [53], who reported a higher ORC value in FD pumpkin flour than in HA samples (2.4 and $1.1 \mathrm{~mL} \cdot \mathrm{g}^{-1}$, resp.). The amount of TDF seemed to be closely related to the ORC of the studied samples, since a negative correlation $\left(R^{2}=0.41\right)$ was found, as it is shown in Figure 1(d). Similar behaviour was observed in the results reported by de Moraes Crizel et al. [42], where olive residue DFC, which had the highest TDF content $\left(53.7 \mathrm{~g} \cdot 100 \mathrm{~g}^{-1} \mathrm{db}\right)$, showed the lowest ORC $\left(2.6 \mathrm{~g} \cdot \mathrm{g}^{-1}\right)$ when compared to pineapple, papaya, and blueberry residue DFC. Regarding $\mathrm{pH}$, all the comparisons between drying treatments showed significant differences $(p<0.05)$. Mango samples presented lower $\mathrm{pH}$ values (4.14 and 4.00 for FD and HA, resp.) than those observed in orange (4.99 and 5.29 for FD and HA, resp.) and prickly pear (5.08 and 5.28 for FD and HA, resp.) powders. $\mathrm{pH}$ values could be explained by the high pectin content in the fruit peels. However, there is not a clear relation between the changes in the IDF or SDF composition with the increment or decrement of $\mathrm{pH}$ values obtained from the DFC dehydrated by both FD and HA.

Finally, TD values ranged from 354 to $804 \mathrm{mg} \cdot \mathrm{mL}^{-1}$; similar density values were reported by Basanta et al. [59] in cherry residue DFC from three different varieties. Higher TD values were found in FD orange and mango peel concentrates (557 and $804 \mathrm{mg} \cdot \mathrm{mL}^{-1}$, resp.) when compared to the HA samples (449 and $724 \mathrm{mg} \cdot \mathrm{mL}^{-1}$, resp.). However, the prickly pear concentrate TD value observed in HA samples was larger than the one observed in FD samples (628 and $354 \mathrm{mg} \cdot \mathrm{mL}^{-1}$, resp.), indicating a most compactable material. Nevertheless, despite the correlations shown in Figure 1, most of the physicochemical properties studied could also depend on the porosity and structure of the fibres produced by the drying process, whereby morphological observations of the fibre structures should be conducted for further studies.

3.3. SCFA Production during In Vitro Fermentation of DFC. The total SCFA production of DFC is given in Table 5. Both orange samples, FD and HA, showed higher SCFA content 
TABLE 4: Physicochemical properties of dietary fibre concentrates from orange, mango, and prickly pear peels freeze-dried (FD) and convective hot air-dried (HA).

\begin{tabular}{|c|c|c|c|c|c|c|}
\hline & SOL (\%) & $\mathrm{SC}\left(\mathrm{mL} \cdot \mathrm{g}^{-1}\right)$ & WRC $\left(\mathrm{mL} \cdot \mathrm{g}^{-1}\right)$ & ORC $\left(\mathrm{mL} \cdot \mathrm{g}^{-1}\right)$ & $\mathrm{pH}$ & $\mathrm{TD}\left(\mathrm{mg} \cdot \mathrm{mL}^{-1}\right)$ \\
\hline $\begin{array}{l}\text { Orange } \\
\text { FD } \\
\text { HA }\end{array}$ & $\begin{array}{l}34.4 \pm 0.4^{\mathrm{b}} \\
44.7 \pm 1.0^{\mathrm{a}}\end{array}$ & $\begin{array}{c}8.1 \pm 0.2^{\mathrm{b}} \\
10.6 \pm 0.3^{\mathrm{a}}\end{array}$ & $\begin{array}{l}3.9 \pm 0.1^{\mathrm{a}} \\
3.4 \pm 0.1^{\mathrm{b}}\end{array}$ & $\begin{array}{l}1.8 \pm 0.1^{\mathrm{b}} \\
2.5 \pm 0.1^{\mathrm{a}}\end{array}$ & $\begin{array}{l}4.99 \pm 0.01^{\mathrm{b}} \\
5.29 \pm 0.01^{\mathrm{a}}\end{array}$ & $\begin{array}{c}557 \pm 8^{\mathrm{a}} \\
449 \pm 10^{\mathrm{b}}\end{array}$ \\
\hline $\begin{array}{l}\text { Mango } \\
\text { FD } \\
\text { HA } \\
\end{array}$ & $\begin{array}{l}51.1 \pm 1.6^{\mathrm{a}} \\
47.1 \pm 0.7^{\mathrm{b}}\end{array}$ & $\begin{array}{l}8.9 \pm 0.2^{\mathrm{a}} \\
6.5 \pm 0.2^{\mathrm{b}}\end{array}$ & $\begin{array}{l}3.7 \pm 0.1^{\mathrm{a}} \\
3.2 \pm 0.0^{\mathrm{b}}\end{array}$ & $\begin{array}{l}1.7 \pm 0.0^{\mathrm{a}} \\
1.7 \pm 0.0^{\mathrm{a}}\end{array}$ & $\begin{array}{l}4.14 \pm 0.01^{\mathrm{a}} \\
4.00 \pm 0.01^{\mathrm{b}}\end{array}$ & $\begin{array}{c}804 \pm 5^{\mathrm{a}} \\
724 \pm 14^{\mathrm{b}}\end{array}$ \\
\hline $\begin{array}{l}\text { Prickly pear } \\
\text { FD } \\
\text { HA }\end{array}$ & $\begin{array}{l}53.9 \pm 1.2^{\mathrm{a}} \\
47.8 \pm 1.4^{\mathrm{b}}\end{array}$ & $\begin{array}{l}11.2 \pm 0.2^{\mathrm{a}} \\
10.2 \pm 0.4^{\mathrm{b}}\end{array}$ & $\begin{array}{l}4.4 \pm 0.1^{\mathrm{a}} \\
3.7 \pm 0.2^{\mathrm{b}}\end{array}$ & $\begin{array}{l}2.6 \pm 0.0^{\mathrm{a}} \\
1.8 \pm 0.1^{\mathrm{b}}\end{array}$ & $\begin{array}{l}5.08 \pm 0.09^{\mathrm{b}} \\
5.28 \pm 0.02^{\mathrm{a}}\end{array}$ & $\begin{array}{c}354 \pm 4^{\mathrm{b}} \\
628 \pm 16^{\mathrm{a}}\end{array}$ \\
\hline
\end{tabular}

Values are mean of four determinations \pm SD. Values per fruit (freeze-dried or convective hot air-dried) within the same column followed by different letters are significantly different $(p<0.05)$. SOL: solubility; SC: swelling capacity; WRC: water retention capacity; ORC: oil retention capacity; TD: tapping density. All physicochemical properties were calculated with dry basis weights.

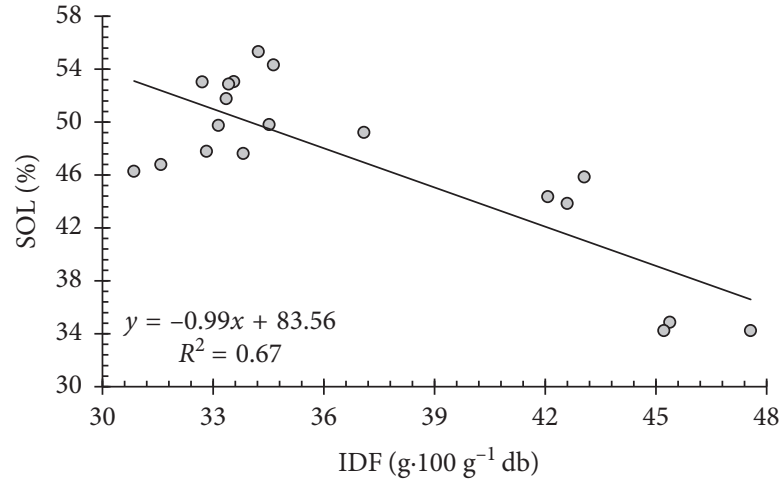

(a)

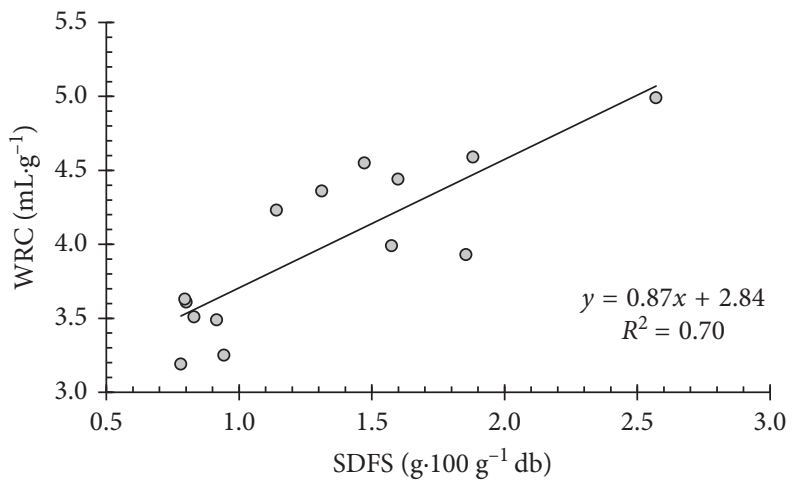

(c)

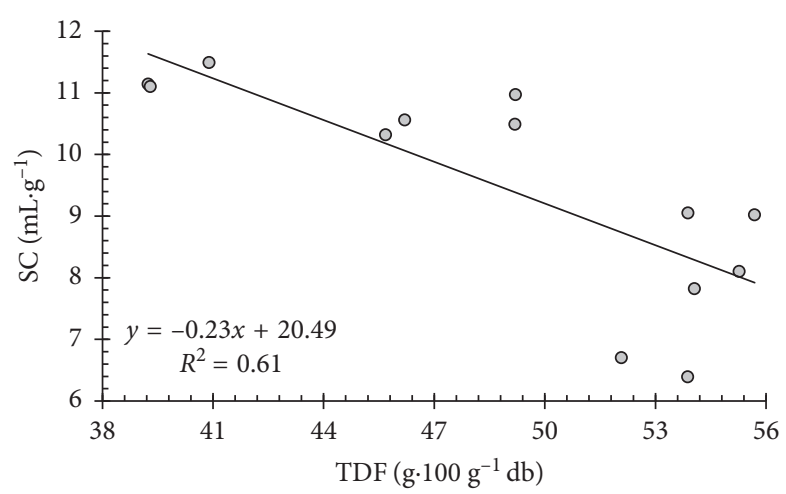

(b)

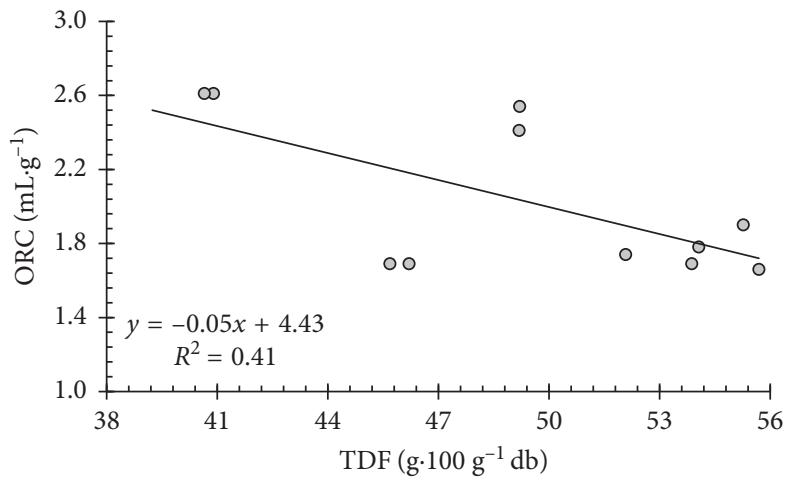

(d)

FIGURE 1: Correlation among physicochemical properties and different dietary fibre fractions: (a) solubility (SOL) and IDF, (b) swelling capacity (SC) and TDF, (c) water retention capacity (WRC) and SDFS, and (d) oil retention capacity (ORC) and TDF of DFC from fruit peels obtained by freeze-drying and convective hot air-drying. TDF: total dietary fibre; IDF: insoluble dietary fibre; SDFS: low-molecular weight soluble dietary fibre.

than mango and prickly pear samples at all fermentation times; in fact, SCFA content was even higher than FOS after $6 \mathrm{~h}$ fermentation. HA orange peel DFC produced significantly $(p<0.05)$ more SCFA $\left(39.6 \mathrm{mmol} \cdot \mathrm{g}^{-1}\right)$ than FD orange samples $\left(34.8 \mathrm{mmol} \cdot \mathrm{g}^{-1}\right)$ after $24 \mathrm{~h}$ fermentation. For their part, FD mango and prickly pear DFC produced higher SCFA at $24 \mathrm{~h}$ than the HA samples. The principal organic acid produced by the fermentation of the DFC was acetate (Figure 2), with more than $70 \%$ of the total SCFA composition. The high acetate production during the in vitro fermentation is explained by the large amount of pectin and/or mucilage, present in the studied fruit peels, which are mainly formed by galacturonic acids, and the presence of uronic acids is involved in the production of acetate, while propionate is primarily produced from glucose, xylose, and arabinose, and butyrate mostly from xylose [60].

Orange samples produced higher acetate concentrations than mango and prickly pear concentrates (Figure 2(a)). Significant higher acetate production $(p<0.05)$ was observed in HA orange DFC after $24 \mathrm{~h}$ fermentation $\left(30 \mathrm{mmol} \cdot \mathrm{g}^{-1}\right)$ 
TABLE 5: Total SCFA production (mmol.g ${ }^{-1} \mathrm{db}$ ) of DFC from orange, mango, and prickly pear peels freeze-dried (FD) and convective hot air-dried (HA), during in vitro faecal fermentation.

\begin{tabular}{|c|c|c|c|c|c|c|c|}
\hline \multirow{2}{*}{ Fermentation time } & \multicolumn{2}{|c|}{ Orange } & \multicolumn{2}{|c|}{ Mango } & \multicolumn{2}{|c|}{ Prickly pear } & \multirow{2}{*}{ FOS } \\
\hline & FD & HA & FD & $\mathrm{HA}$ & FD & HA & \\
\hline $6 \mathrm{~h}$ & $13.6 \pm 0.5^{\mathrm{a}}$ & $15.9 \pm 0.5^{\mathrm{b}}$ & $4.3 \pm 0.3^{\mathrm{a}}$ & $4.4 \pm 0.2^{\mathrm{a}}$ & $10.5 \pm 0.2^{\mathrm{a}}$ & $5.7 \pm 0.2^{\mathrm{b}}$ & $5.1 \pm 0.3$ \\
\hline $12 \mathrm{~h}$ & $31.7 \pm 0.6^{\mathrm{a}}$ & $31.7 \pm 0.7^{\mathrm{a}}$ & $13.0 \pm 0.4^{\mathrm{a}}$ & $13.0 \pm 0.3^{\mathrm{a}}$ & $21.0 \pm 1.7^{\mathrm{a}}$ & $15.1 \pm 0.4^{\mathrm{b}}$ & $35.1 \pm 1.1$ \\
\hline $24 \mathrm{~h}$ & $34.8 \pm 0.3^{\mathrm{b}}$ & $39.6 \pm 0.5^{\mathrm{a}}$ & $18.3 \pm 0.6^{\mathrm{a}}$ & $16.8 \pm 0.2^{\mathrm{b}}$ & $28.2 \pm 0.7^{\mathrm{a}}$ & $26.3 \pm 1.0^{\mathrm{a}}$ & $49.6 \pm 0.9$ \\
\hline
\end{tabular}

Values are mean of three determinations \pm SD. Values per fruit (freeze-dried or convective hot air-dried) within the same row followed by different letters are significantly different $(p<0.05)$. FOS were used as a positive control.

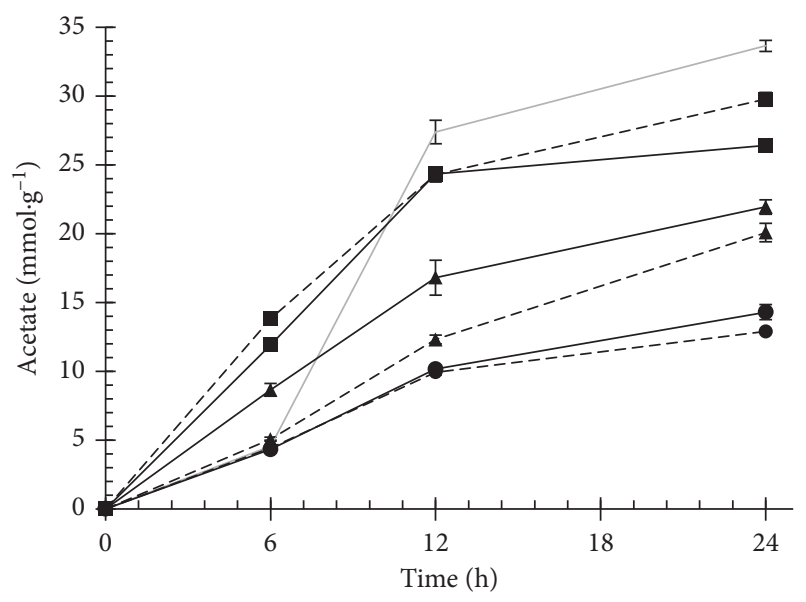

(a)

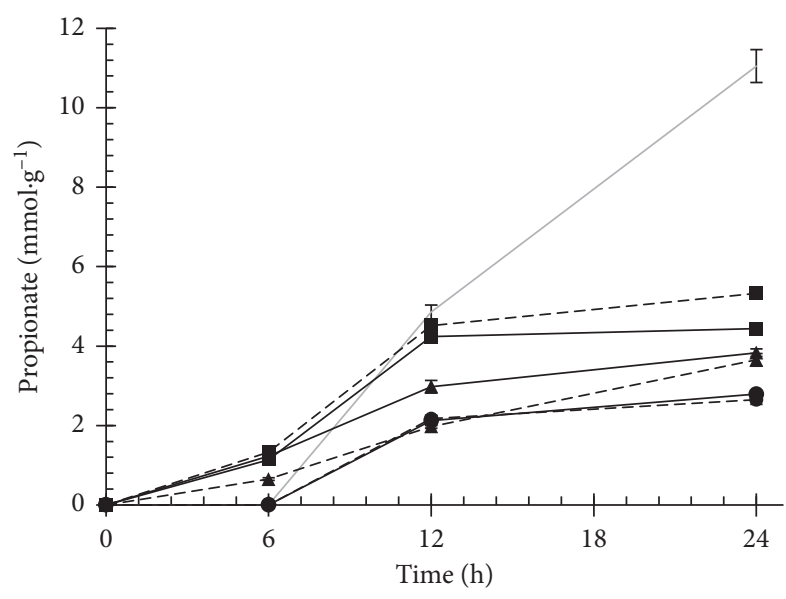

(b)

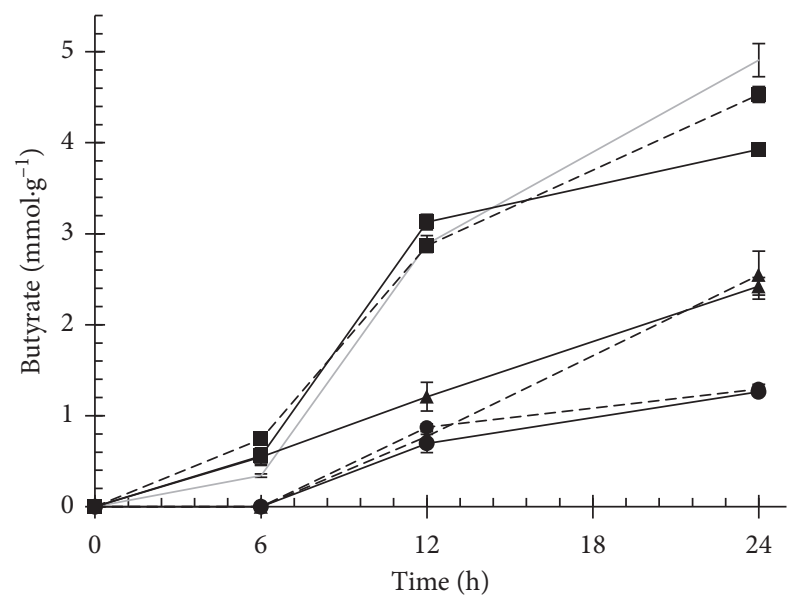

(c)

Figure 2: Acetate (a), propionate (b), and butyrate (c) production after $24 \mathrm{~h}$ of in vitro faecal fermentation of orange ( $\bullet$ ), mango (•), and prickly pear ( $\mathbf{\Delta})$ peel concentrates obtained by freeze-drying $(-)$ and convective hot air-drying (--). Fermentation of FOS (grey line) was used as a positive control.

than that obtained from FD orange samples $\left(26 \mathrm{mmol} \cdot \mathrm{g}^{-1}\right)$; however, at the first $6 \mathrm{~h}$, HA orange peel samples produced $13.8 \mathrm{mmol} \cdot \mathrm{g}^{-1}$, compared to $11.9 \mathrm{mmol} \cdot \mathrm{g}^{-1}$ obtained from FD samples. Mango peel samples showed the lowest values at the three fermentation times, and significant differences $(p<0.05)$ between FD and HA were only observed after $24 \mathrm{~h}$ (14.3 and $12.9 \mathrm{mmol} \cdot \mathrm{g}^{-1}$, resp.). The production of acetate in FD prickly pear was significantly higher at all the evaluated times than that of HA samples.

Propionate production (Figure 2(b)) was the highest in orange (4.4 and $5.3 \mathrm{mmol} \cdot \mathrm{g}^{-1}$ for FD and HA, resp., at $24 \mathrm{~h}$ ) and the lowest in mango peel samples $\left(2.8\right.$ and $2.6 \mathrm{mmol} \cdot \mathrm{g}^{-1}$ for FD and HA, resp., at $24 \mathrm{~h})$. Significant differences $(p<0.05)$ were observed due to the drying methods applied in orange, where the HA samples produced more propionate; however, both dried mango samples produced similar propionate concentrations. Prickly pear DFC samples produced significantly more propionate than HA samples after 6 and $12 \mathrm{~h}$.

Regarding butyrate production (Figure 2(c)), orange samples produced 3.9 and $4.5 \mathrm{mmol} \cdot \mathrm{g}^{-1}$ for FD and HA treatments, respectively. Butyrate produced by HA samples 
was significantly higher than that produced by FD. Besides, no significant differences $(p<0.05)$ were found among these values and the value produced by FOS fermentation $\left(4.9 \mathrm{mmol} \cdot \mathrm{g}^{-1}\right)$; therefore, HA favoured butyrate production in this fruit DFC. No differences were observed between drying methods in mango peel samples, which reached the maximum value after $24 \mathrm{~h}$ of $1.3 \mathrm{mmol} \cdot \mathrm{g}^{-1}$. FD prickly pear samples produced higher values than HA after $12 \mathrm{~h}$, but no significant differences $(p<0.05)$ were observed at $24 \mathrm{~h}$. Butyrate is a desirable end-fermentation product because it is the principal energy source of the colon epithelial cells, and it has antineoplastic properties, which may prevent colorectal cancer $[61,62]$. Thus, a high butyrate production, such as in the orange peel DFC case, is of special attention. On the contrary, no propionate and butyrate production was observed in mango peel samples (FD and HA) and FOS after $6 \mathrm{~h}$ of fermentation, indicating that high SDF content resulted in a slow fermentation rate, despite the fact that SDF is considered as easy to be consumed by colonic bacteria [63].

It is important to remark that the final production of SCFA of all the samples after $24 \mathrm{~h}$ negatively correlates to the SDF: TDF ratio shown in Table $3\left(R^{2}=0.87\right.$; correlation plots are not shown), independently if the SDF:TDF value depends on the fruit or if it is produced by the drying method. High correlation values were also observed, not only between SDF: TDF and acetate production $\left(R^{2}=0.89\right)$, which is the main organic acid that constitutes the total SCFA value, but also with propionate $\left(R^{2}=0.82\right)$ and butyrate $\left(R^{2}=0.77\right)$ contents. Although it is commonly accepted that there is a relationship between SDF and the fermentation produced by the colonic microbiota [64], our results show that a high SDF content inhibited the production of SCFA in in vitro fermentation. A possible explanation is that the easily metabolized SDF could already be used in different metabolic pathways by the probiotic bacteria. This is also supported by the lack of propionate and butyrate produced by mango DFC (SDF:TDF $\approx 0.40)$ after $6 \mathrm{~h}$. In this regard, further studies on the microbial population and substrate assimilation must be conducted. On the contrary, increases in the IDF content resulted in higher organic acid production. IDF digestion by the colonic bacteria is highly influenced by the accessibility of the microbial enzymes to the fibre [63]; therefore, the prebiotic potential of the DFC depends not only on the composition but also on the physicochemical and morphological properties of the IDF produced during the dehydration process. Finally, a very low correlation was found between the production of total SCFA and TDF content $\left(R^{2}=0.04\right)$. Therefore, it is not only the fibre content in the concentrates what promotes the production of organic acids but also the dietary fibre composition and SDF:TDF ratio.

\section{Conclusions}

FD and HA were successfully used to obtain DFC from orange, mango, and prickly pear peels, with high dietary fibre content. The method used to dehydrate mango peels did not modify the fibre content. However, IDF and SDF in prickly pear sample composition considerably increased with HA (6.7 and $7.2 \mathrm{~g} \cdot 100 \mathrm{~g}^{-1} \mathrm{db}$, resp.) when compared to FD samples, whereas IDF and SDF in orange peel DFC were decreased by HA (3.5 and $1.1 \mathrm{~g} \cdot 100 \mathrm{~g}^{-1} \mathrm{db}$, resp.). SOL and $\mathrm{SC}$ were the most affected physicochemical properties by the drying treatments, where higher values were obtained for orange dried with HA, while FD improved these properties in mango and prickly pear. All the DFC studied used as a carbon source in in vitro faecal fermentation produced an acceptable SCFA content, when compared to the organic acids produced by FOS. HA orange DFC produced more SCFA ( $48 \mathrm{mmol} \cdot \mathrm{g}^{-1}$ higher) than the FD sample, while FD enhanced organic acid production in mango and prickly pear samples. However, it was observed that the lower SDF: TDF ratio by either the specific content of the fruit or the content modified by the drying method favoured the SCFA production, and differently of what has been previously reported, in these systems, an increase in IDF improves SCFA production. The studied peel DFC have similar physicochemical and functional properties. However, from the point of view of the SCFA production in in vitro fermentation, as a prebiotic potential indicator, the orange DFC dried by HA is the most suitable, whereas mango peel obtained by the same drying process is the sample that showed the lowest prebiotic properties.

\section{Conflicts of Interest}

The authors declare that there are no conflicts of interest regarding the publication of this paper.

\section{Acknowledgments}

Garcia-Amezquita and Tejada-Ortigoza acknowledge the support from Tecnológico de Monterrey (Research Chair Funds GEE1A01001 and CDB081) and the Mexican National Council of Science and Technology (CONACYT) Scholarship Program (Grant nos. 260692 and 205265). This work was supported by CONACYT, through Project no. CB-201401-237271.

\section{References}

[1] J. L. Causey, J. M. Fertag, D. D. Gallaher, B. C. Tungland, and J. L. Slavin, "Effects of dietary inulin on serum lipids, blood glucose and the gastrointestinal environment in hypercholesterolemic men," Nutrition Research, vol. 20, no. 2, pp. 191-201, 2000.

[2] M. M. Kaczmarczyk, M. J. Miller, and G. G. Freund, "The health benefits of dietary fiber: beyond the usual suspects of type 2 diabetes mellitus, cardiovascular disease and colon cancer," Metabolism, vol. 61, no. 8, pp. 1058-1066, 2012.

[3] J. W. DeVries, M. E. Camire, S. Cho et al., "The definition of dietary fiber," Cereal Foods World, vol. 46, no. 3, pp. 112-129, 2001.

[4] ALINORM 09/32/26, Report of the 30th Session of the Codex Committee on Nutrition and Foods for Special Dietary Uses, 2008.

[5] F. Figuerola, M. L. Hurtado, A. M. Estévez, I. Chiffelle, and F. Asenjo, "Fibre concentrates from apple pomace and citrus 
peel as potential fibre sources for food enrichment," Food Chemistry, vol. 91, no. 3, pp. 395-401, 2005.

[6] J. W. Anderson and S. R. Bridges, "Dietary fiber content of selected foods," American Journal of Clinical Nutrition, vol. 47, no. 3, pp. 440-447, 1988.

[7] V. Tejada-Ortigoza, L. E. Garcia-Amezquita, S. O. SernaSaldívar, and J. Welti-Chanes, "Advances in the functional characterization and extraction processes of dietary fiber," Food Engineering Reviews, vol. 8, no. 3, pp. 251-271, 2016.

[8] V. Tejada-Ortigoza, L. E. Garcia-Amezquita, S. O. SernaSaldivar, and J. Welti-Chanes, "The dietary fiber profile of fruit peels and functionality modifications induced by high hydrostatic pressure treatments," Food Science and Technology International, vol. 23, no. 5, pp. 396-402, 2017.

[9] N. Grigelmo-Miguel, S. Gorinstein, and O. Martín-Belloso, "Characterisation of peach dietary fibre concentrate as a food ingredient," Food Chemistry, vol. 65, no. 2, pp. 175-181, 1999.

[10] C. Soukoulis, D. Lebesi, and C. Tzia, "Enrichment of ice cream with dietary fibre: effects on rheological properties, ice crystallisation and glass transition phenomena," Food Chemistry, vol. 115, no. 2, pp. 665-671, 2009.

[11] N. Grigelmo-Miguel, E. Carreras-Boladeras, and O. MartínBelloso, "Development of high-fruit-dietary-fibre muffins," European Food Research and Technology, vol. 210, no. 2, pp. 123-128, 1999.

[12] L. E. Garcia-Amezquita, V. Tejada-Ortigoza, S. O. SernaSaldívar, and J. Welti-Chanes, "Dietary fiber concentrates from fruit and vegetable by-products: processing, modification, and application as functional ingredients," Food and Bioprocess Technology, 2018, In press.

[13] D. M. Amaya-Cruz, S. Rodríguez-González, I. F. PérezRamírez et al., "Juice by-products as a source of dietary fibre and antioxidants and their effect on hepatic steatosis," Journal of Functional Foods, vol. 17, pp. 93-102, 2015.

[14] T. de Moraes Crizel, A. Jablonski, A. de Oliveira Rios, R. Rech, and S. H. Flôres, "Dietary fiber from orange byproducts as a potential fat replacer," LWT-Food Science and Technology, vol. 53, no. 1, pp. 9-14, 2013.

[15] V. Stojceska, P. Ainsworth, A. Plunkett, E. Ibanoğlu, and Ş. Ibanoğlu, "Cauliflower by-products as a new source of dietary fibre, antioxidants and proteins in cereal based readyto-eat expanded snacks," Journal of Food Engineering, vol. 87, no. 4 , pp. 554-563, 2008.

[16] J. A. Larrauri, "New approaches in the preparation of high dietary fibre powders from fruit by-products," Trends in Food Science and Technology, vol. 10, no. 1, pp. 3-8, 1999.

[17] C. Borchani, S. Besbes, M. Masmoudi, M. A. Bouaziz, C. Blecker, and H. Attia, "Influence of oven-drying temperature on physicochemical and functional properties of date fibre concentrates," Food Bioprocess Technology, vol. 5, no. 5, pp. 1541-1551, 2012.

[18] L. E. Garcia-Amezquita, J. Welti-Chanes, F. T. VergaraBalderas, and D. Bermúdez-Aguirre, "Freeze-drying: the basic process," in Encyclopedia of Food and Health, vol. 3, pp. 104-109, Elsevier Ltd., Oxford, London, 2016.

[19] J. Slavin, "Fiber and prebiotics: mechanisms and health benefits," Nutrients, vol. 5, no. 4, pp. 1417-1435, 2013.

[20] G. R. Gibson and M. B. Roberfroid, "Dietary modulation of the human colonic microbiota: introducing the concept of prebiotics," Nutrition Research Reviews, vol. 17, no. 2, pp. 259-275, 2004.

[21] G. Mandalari, C. Nueno Palop, K. Tuohy et al., "In vitro evaluation of the prebiotic activity of a pectic oligosacchariderich extract enzymatically derived from bergamot peel,"
Applied Microbiology and Biotechnology, vol. 73, no. 5, pp. 1173-1179, 2007.

[22] I. A. Rubel, E. E. Pérez, D. B. Genovese, and G. D. Manrique, "In vitro prebiotic activity of inulin-rich carbohydrates extracted from Jerusalem artichoke (Helianthus tuberosus L.) tubers at different storage times by Lactobacillus paracasei," Food Research International, vol. 62, pp. 59-65, 2014.

[23] S. F. Reis, B. Gullón, P. Gullón et al., "Evaluation of the prebiotic potential of arabinoxylans from brewer's spent grain," Applied Microbiology and Biotechnology, vol. 98, no. 22, pp. 9365-9373, 2014.

[24] E. Gomez, K. M. Tuohy, G. R. Gibson, A. Klinder, and A. Costabile, "In vitro evaluation of the fermentation properties and potential prebiotic activity of Agave fructans," Journal of Applied Microbiology, vol. 108, no. 6, pp. 2114-2121, 2010.

[25] J. Diaz-Vela, A. Totosaus, A. E. Cruz-Guerrero, and M. De Lourdes Pérez-Chabela, "In vitro evaluation of the fermentation of added-value agroindustrial by-products: cactus pear (Opuntia ficus-indica L.) peel and pineapple (Ananas comosus) peel as functional ingredients," International Journal of Food Science \& Technology, vol. 48, no. 7, pp. 1460-1467, 2013.

[26] E. Sánchez-Zapata, J. Fernández-López, J. A. Pérez-Alvarez et al., "In vitro evaluation of "horchata" co-products as carbon source for probiotic bacteria growth," Food and Bioproducts Processing, vol. 91, no. 3, pp. 279-286, 2013.

[27] AOAC, Official Methods of Analysis, AOAC International, Arlington, VA, USA, 15th edition, 1996.

[28] B. V. McCleary, "Modification to AOAC official methods 2009.01 and 2011.25 to allow for minor overestimation of low molecular weight soluble dietary fiber in samples containing starch," Journal of AOAC International, vol. 97, no. 3, pp. 896-901, 2014.

[29] C.-F. Chau and Y.-L. Huang, "Comparison of the chemical composition and physicochemical properties of different fibers prepared from the peel of Citrus sinensis L. Cv. Liucheng," Journal of Agricultural and Food Chemistry, vol. 51, no. 9, pp. 2615-2618, 2003.

[30] D. J. Rose, J. A. Patterson, and B. R. Hamaker, "Structural differences among alkali-soluble arabinoxylans from maize (Zea mays), rice (Oryza sativa), and wheat (Triticum aestivum) brans influence human fecal fermentation profiles," Journal of Agricultural and Food Chemistry, vol. 58, no. 1, pp. 493-499, 2010.

[31] Y. E. Tuncil, C. H. Nakatsu, A. E. Kazem et al., "Delayed utilization of some fast-fermenting soluble dietary fibers by human gut microbiota when presented in a mixture," Journal of Functional Foods, vol. 32, pp. 347-357, 2017.

[32] R. Torres, E. J. Montes, O. A. Pérez, and R. D. Andrade, "Relation of color and maturity stage with physicochemical properties of tropical fruits," Información tecnológica, vol. 24, no. 3, pp. 51-56, 2013.

[33] D. M. Jiménez-Aguilar, J. M. López-Martínez, C. HernándezBrenes, J. A. Gutiérrez-Uribe, and J. Welti-Chanes, "Dietary fiber, phytochemical composition and antioxidant activity of Mexican commercial varieties of cactus pear," Journal of Food Composition and Analysis, vol. 41, pp. 66-73, 2015.

[34] M. Olmo, A. Nadas, and J. M. García, "Nondestructive methods to evaluate maturity level of oranges," Journal of Food Science, vol. 65, no. 2, pp. 365-369, 2000.

[35] P. Peerajit, N. Chiewchan, and S. Devahastin, "Effects of pretreatment methods on health-related functional properties 
of high dietary fibre powder from lime residues," Food Chemistry, vol. 132, no. 4, pp. 1891-1898, 2012.

[36] P. Naknaen, T. Itthisoponkul, A. Sondee, and N. Angsombat, "Utilization of watermelon rind waste as a potential source of dietary fiber to improve health promoting properties and reduce glycemic index for cookie making," Food Science and Biotechnology, vol. 25, no. 2, pp. 415-424, 2016.

[37] J. Ahmed, A. Almusallam, and S. N. Al-Hooti, "Isolation and characterization of insoluble date (Phoenix dactylifera L.) fibers," LWT-Food Science and Technology, vol. 50, no. 2, pp. 414-419, 2013.

[38] C. L. Hsu, W. Chen, Y. M. Weng, and C. Y. Tseng, "Chemical composition, physical properties, and antioxidant activities of yam flours as affected by different drying methods," Food Chemistry, vol. 83, no. 1, pp. 85-92, 2003.

[39] Z. W. Cui, C. Y. Li, C. F. Song, and Y. Song, "Combined microwave-vacuum and freeze drying of carrot and apple chips," Drying Technology, vol. 26, no. 12, pp. 1517-1523, 2008.

[40] P. Hazaveh, A. Mohammadi Nafchi, and H. Abbaspour, "The effects of sugars on moisture sorption isotherm and functional properties of cold water fish gelatin films," International Journal of Biological Macromolecules, vol. 79, pp. 370-376, 2015.

[41] T. Nharingo and M. Moyo, "Application of Opuntia ficus-indica in bioremediation of wastewaters. A critical review," Journal of Environmental Management, vol. 166, pp. 55-72, 2016.

[42] T. de Moraes Crizel, V. S. Hermes, A. de Oliveira Rios, and S. H. Flôres, "Evaluation of bioactive compounds, chemical and technological properties of fruits byproducts powder," Journal of Food Science and Technology, vol. 53, no. 11, pp. 4067-4075, 2016.

[43] M. C. López-Marcos, C. Bailina, M. Viuda-Martos, J. A. Pérez-Alvarez, and J. Fernández-López, "Properties of dietary fibers from agroindustrial coproducts as source for fiber-enriched foods," Food Bioprocess Technology, vol. 8, no. 12, pp. 2400-2408, 2015.

[44] L. E. Garcia-Amezquita, V. Tejada-Ortigoza, E. Heredia-Olea, S. O. Serna-Saldívar, and J. Welti-Chanes, "Differences in the dietary fiber content of fruits and their by-products quantified by conventional and integrated AOAC official methodologies," Journal of Food Composition and Analysis, vol. 67, pp. 77-85, 2018.

[45] S. Mallek-Ayadi, N. Bahloul, and N. Kechaou, "Characterization, phenolic compounds and functional properties of Cucumis melo L. peels," Food Chemistry, vol. 221, pp. 1691-1697, 2017.

[46] C. M. Ajila, K. Leelavathi, and U. J. S. Prasada Rao, "Improvement of dietary fiber content and antioxidant properties in soft dough biscuits with the incorporation of mango peel powder," Journal of Cereal Science, vol. 48, no. 2, pp. 319-326, 2008.

[47] Q. Deng, M. H. Penner, and Y. Zhao, "Chemical composition of dietary fiber and polyphenols of five different varieties of wine grape pomace skins," Food Research International, vol. 44, no. 9, pp. 2712-2720, 2011.

[48] A. Vega-Gálvez, L. Zura-Bravo, R. Lemus-Mondaca et al., "Influence of drying temperature on dietary fibre, rehydration properties, texture and microstructure of Cape gooseberry (Physalis peruviana L.)," Journal of Food Science and Technology, vol. 52, no. 4, pp. 2304-2311, 2015.

[49] J. A. Klavons, R. D. Bennett, and S. H. Vannier, "Physical/ chemical nature of pectin associated commercial orange juice cloud," Journal of Food Science, vol. 59, no. 2, pp. 399-401, 1994.

[50] A. Femenia, R. R. Selvendran, S. G. Ring, and J. A. Robertson, "Effects of heat treatment and dehydration on properties of cauliflower fiber," Journal of Agricultural and Food Chemistry, vol. 47, no. 2, pp. 728-732, 1999.
[51] J. M. Campbell, L. L. Bauer, G. C. Fahey, A. J. C. L. Hogarth, B. W. Wolf, and D. E. Hunter, "Selected fructooligosaccharide (1-kestose, nystose, and $1 \mathrm{~F}$ - $\beta$-fructofuranosylnystose) composition of foods and feeds," Journal of Agricultural and Food Chemistry, vol. 45, no. 8, pp. 3076-3082, 1997.

[52] C. L'Homme, M. Arbelot, A. Puigserver, and A. Biagini, "Kinetics of hydrolysis of fructooligosaccharides in mineralbuffered aqueous solutions: influence of $\mathrm{pH}$ and temperature," Journal of Agricultural and Food Chemistry, vol. 51, no. 1, pp. 224-228, 2003.

[53] F. Que, L. Mao, X. Fang, and T. Wu, "Comparison of hot airdrying and freeze-drying on the physicochemical properties and antioxidant activities of pumpkin (Cucurbita moschata Duch.) flours," International Journal of Food Science and Technology, vol. 43, no. 7, pp. 1195-1201, 2008.

[54] Y. L. Huang and Y. S. Ma, "The effect of extrusion processing on the physiochemical properties of extruded orange pomace," Food Chemistry, vol. 192, pp. 363-369, 2016.

[55] R. Martínez, P. Torres, M. A. Meneses, J. G. Figueroa, J. A. Pérez-Álvarez, and M. Viuda-Martos, "Chemical, technological and in vitro antioxidant properties of mango, guava, pineapple and passion fruit dietary fibre concentrate," Food Chemistry, vol. 135, no. 3, pp. 1520-1526, 2012.

[56] N. O'Shea, A. Ktenioudaki, T. P. Smyth et al., "Physicochemical assessment of two fruit by-products as functional ingredients: apple and orange pomace," Journal of Food Engineering, vol. 153, pp. 89-95, 2015.

[57] P. Chantaro, S. Devahastin, and N. Chiewchan, "Production of antioxidant high dietary fiber powder from carrot peels," LWT-Food Science and Technology, vol. 41, no. 10, pp. 1987-1994, 2008.

[58] S. N. Raghavendra, S. R. Ramachandra Swamy, N. K. Rastogi, K. S. M. S. Raghavarao, S. Kumar, and R. N. Tharanathan, "Grinding characteristics and hydration properties of coconut residue: a source of dietary fiber," Journal of Food Engineering, vol. 72, no. 3, pp. 281-286, 2006.

[59] M. F. Basanta, M. F. De Escalada Plá, M. D. Raffo, C. A. Stortz, and A. M. Rojas, "Cherry fibers isolated from harvest residues as valuable dietary fiber and functional food ingredients," Journal of Food Engineering, vol. 126, pp. 149-155, 2014.

[60] V. Salvador, C. Cherbut, J. L. Barry, D. Bertrand, C. Bonnet, and J. Delort-Laval, "Sugar composition of dietary fibre and short-chain fatty acid production during in vitro fermentation by human bacteria," British Journal of Nutrition, vol. 70, no. 1, pp. 189-197, 1993.

[61] E. Olano-Martin, K. C. Mountzouris, G. R. Gibson, and R. A. Rastall, "In vitro fermentability of dextran, oligodextran and maltodextrin by human gut bacteria," British Journal of Nutrition, vol. 83, no. 3, pp. 247-255, 2000.

[62] L. De Vuyst and F. Leroy, "Cross-feeding between bifidobacteria and butyrate-producing colon bacteria explains bifdobacterial competitiveness, butyrate production, and gas production," International Journal of Food Microbiology, vol. 149, no. 1, pp. 73-80, 2011.

[63] S. A. Hughes, P. R. Shewry, L. Li, G. R. Gibson, M. L. Sanz, and R. A. Rastall, "In vitro fermentation by human fecal microflora of wheat arabinoxylans," Journal of Agricultural and Food Chemistry, vol. 55, no. 11, pp. 4589-4595, 2007.

[64] N. Roland, L. Nugon-Baudon, C. Andrieux, and O. Szylit, "Comparative study of the fermentative characteristics of inulin and different types of fibre in rats inoculated with a human whole faecal flora," British Journal of Nutrition, vol. 74, no. 2, pp. 239-249, 1995. 


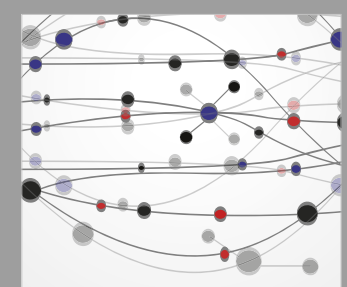

The Scientific World Journal
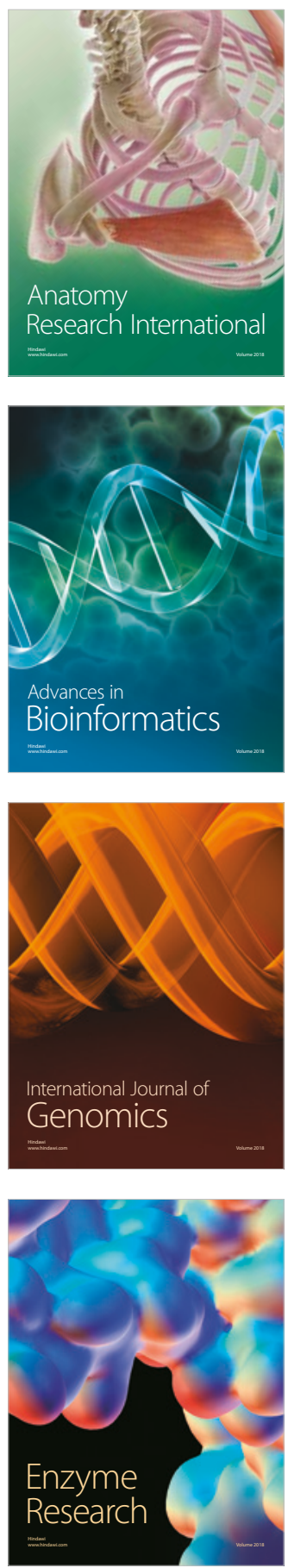
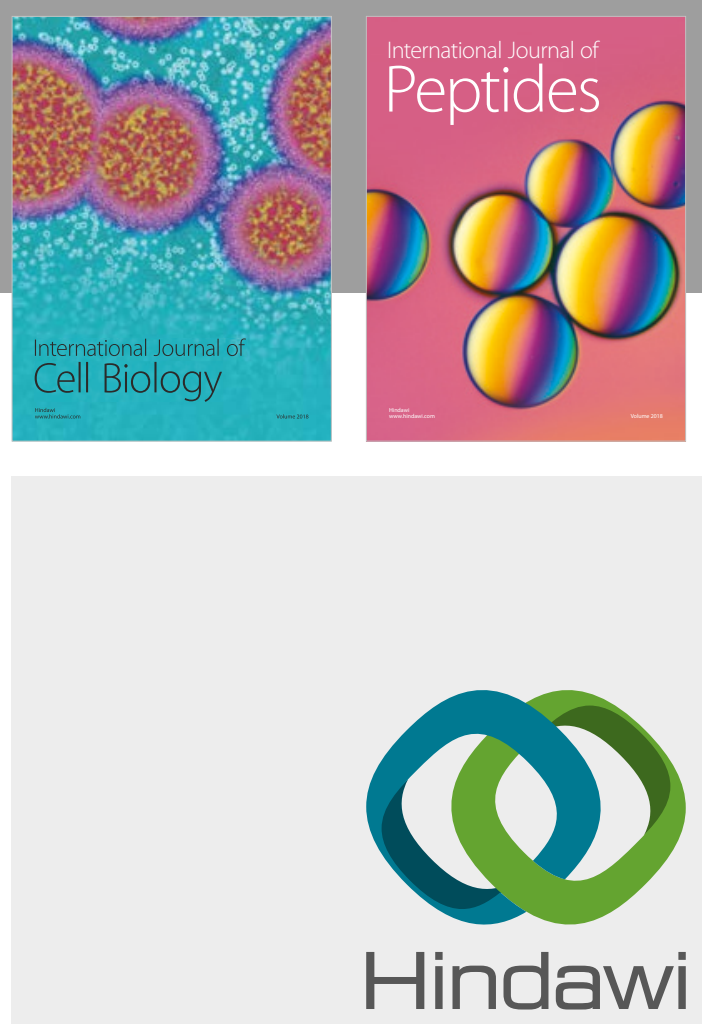

Submit your manuscripts at

www.hindawi.com
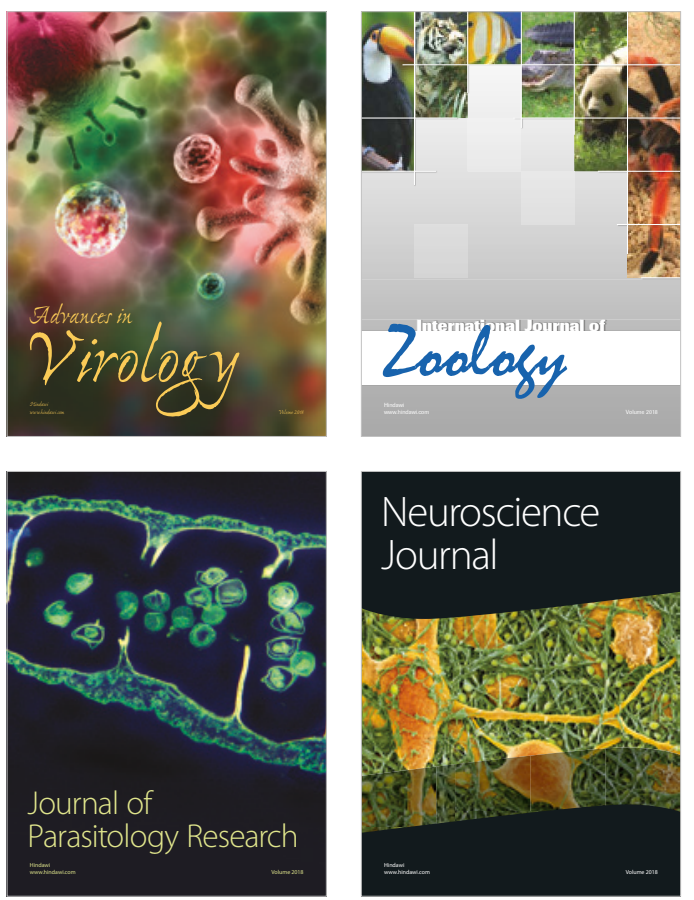
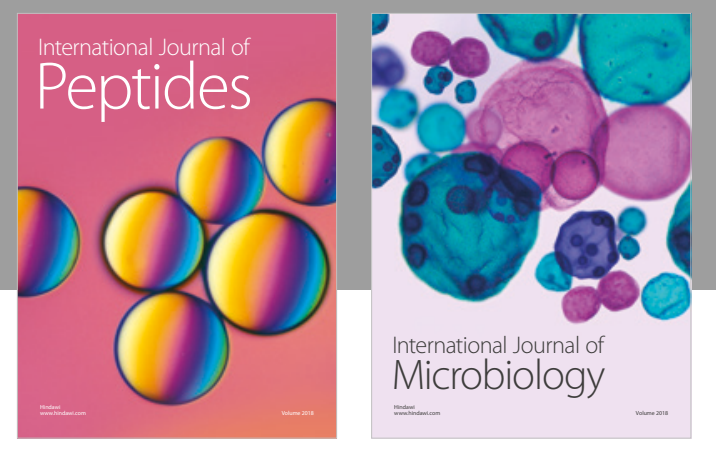

nternational Journal of Microbiology
Journal of
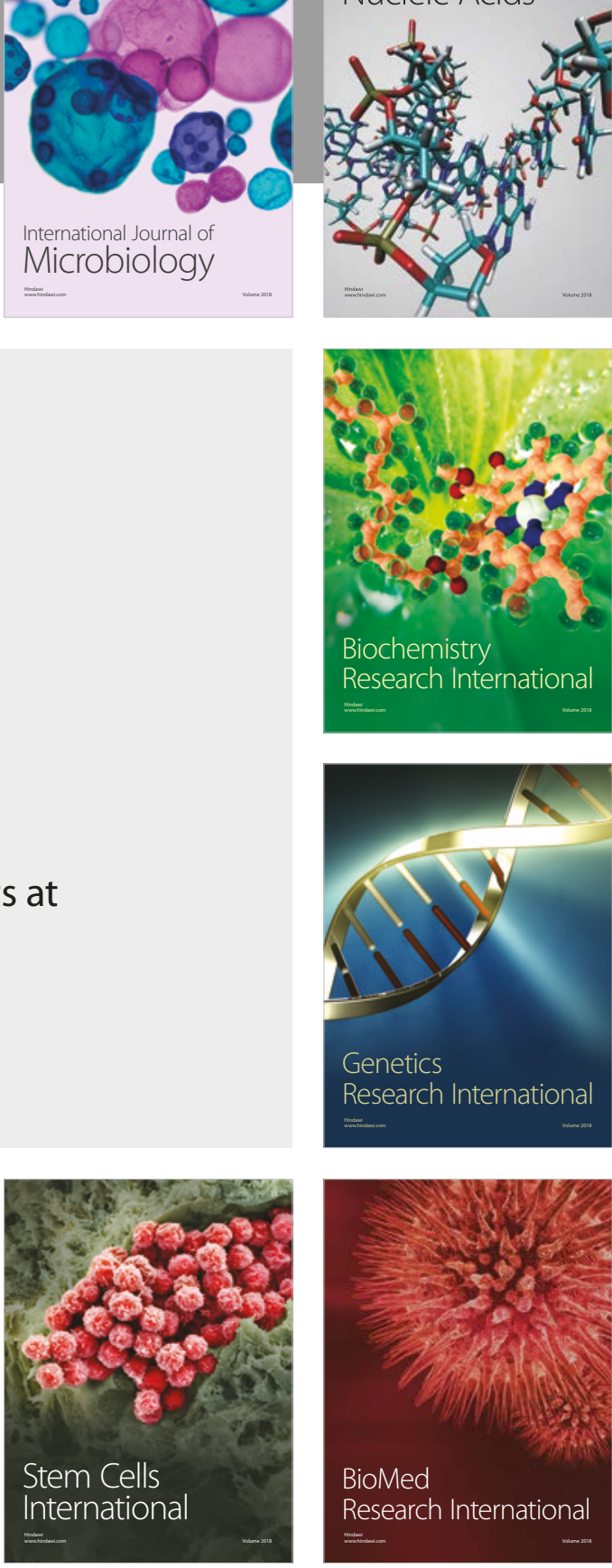
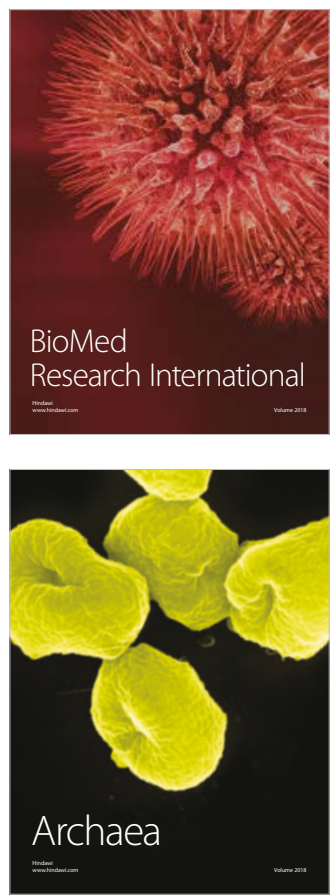